\title{
Pengendalian Hayati Penyakit Hawar Daun Tanaman Kentang Dengan Agens Hayati Jamur-jamur Antagonis Isolat Lokal
}

\author{
Susiana Purwantisari, Rejeki Siti Ferniah, Budi Raharjo \\ Lab. Mikrobiogenetika Jurusan Biologi FMIPA Undip
}

\begin{abstract}
Abstrak
Penyakit hawar daun tanaman kentang atau yang oleh petani di Kedu, Wonosobo disebut Lodoh merupakan penyakit yang paling serius di antara penyakit dan hama yang menyerang tanaman kentang di Indonesia. Penyakit lodoh ini disebabkan oleh serangan jamur patogen ganas Phytophthora infestans yang dapat menurunkan produksi kentang hingga 90\% dari total produksi kentang dalam waktu yang amat singkat. Sampai saat ini kapang patogen penyebab penyakit busuk batang dan daun tanaman kentang tersebut masih merupakan masalah krusial dan belum ada fungisida yang benar-benar efektif terhadap penyakit tersebut. Penelitian ini bertujuan mengoleksi dan mengidentifikasi jamur-jamur tanah isolat lokal yang bersifat antagonis terhadap patogen penyebab penyakit busuk daun dan umbi tanaman kentang. Hasil penelitian menunjukkan bahwa penyebab penyakit busuk daun dan umbi tanaman kentang di daerah sentra pembibitan tanaman kentang di Kedu Temanggung Jawa Tengah adalah Phytophthora infestans. Terdapat 17 isolat jamur isolat lokal yang dapat diisolasi dari tanah di sentra pembibitan tanaman kentang tersebut. Dari 17 isolat jamur ini dapat dikelompokkan menjadi 4 kelompok isolat yang berbeda morfologi koloninya. Pengamatan secara mikroskopis menunjukkan bahwa dari 4 kelompok jamur tanah tersebut adalah dari marga Trichoderma spp, Aspergillus sp, Penicillium sp dan Phytophthora infestans.
\end{abstract}

Kata Kunci: Jamur antagonis, kentang, busuk daun, Phytophthora infestans.

\section{PENDAHULUAN}

Kentang adalah salah satu komoditi andalan sektor pertanian di Indonesia dan semakin meningkat permintaannya akhir-akhir ini. Peningkatan ini untuk mencukupi kebutuhan bahan pengganti makanan pokok (beras) maupun sebagai bahan baku industri, selain itu untuk mengatasi harga beras yang semakin tinggi serta mengurangi impor bahan pangan beras yang telah menghabiskan devisa negara dalam jumlah besar (Anonim, 2002). Salah satu prioritas pengembangan agribisnis kentang di Indonesia adalah di Jawa Tengah (Wonosobo), namun produksinya masih rendah oleh serangan organisme pengganggu tanaman (OPT) khususnya kapang patogen Phytophthora infestans penyebab busuk daun dan umbi tanaman kentang (Rukmana, 1997). Secara bertahap dan berkesinambungan penelitian intensif terhadap komoditas kentang mendapat perhatian dan prioritas. Pengembangan agribisnis kentang diprioritaskan antara lain di provinsi Jawa Barat, Jawa Timur, Jawa Tengah, Sumatra Utara, Sumatra Barat dan Sulawesi Selatan
Penyakit merupakan salah satu faktor pembatas penting pada budidaya tanaman kentang. Penyakit busuk daun tanaman kentang atau yang oleh petani di Wonosobo dan Dieng disebut Lodoh merupakan penyakit yang paling serius di antara penyakit dan hama yang menyerang tanaman kentang di Indonesia (Katayama \& Teramoto, 1997; Zazali, 2004). Penyakit lodoh disebabkan oleh serangan jamur patogen ganas Phytophthora infestans ini dapat menurunkan produksi kentang hingga $90 \%$ dari total produksi kentang dalam waktu yang amat singkat. Sampai saat ini kapang patogen penyebab penyakit busuk batang dan daun tanaman kentang tersebut masih merupakan masalah krusial dan belum ada varietas kentang yang benar-benar tahan terhadap penyakit tersebut (Cholil, 1991).

Menurut Djafaruddin, (2000), penyakit busuk daun/batang (late blight) tanaman kentang sangat berpotensi terjadi pada daerah dingin dan lembab karena kapang patogen yang menyebabkannya mudah tumbuh dan berkembang baik pada kondisi dingin. Penyebab penyakit busuk daun ini adalah kapang patogen 
Phytophthora infestans. Kapang dapat menyerang daun, batang, juga umbi di dalam tanah. Kapang patogen Phytophthora infestans bukan merupakan kapang asli tanah, namun biasa menyerang organorgan tanaman kentang di dalam tanah dan di atas tanah (daun, batang, cabang, akar dan umbi).

Penyebaran spora patogen kapang melalui angin, air atau serangga. Jika spora sampai ke daun basah, ia akan berkecambah dengan mengeluarkan zoospora atau langsung membentuk tabung kecambah, kemudian masuk ke bagian tanaman, dan akhirnya terjadi infeksi. Spora yang jatuh ke tanah akan menginfeksi umbi, dan pembusukannya bisa terjadi di dalam tanah atau di tempat penyimpanan. Kasus penyakit busuk daun biasanya sering terjadi di daerah dataran tinggi yang bersuhu rendah dengan kelembaban tinggi (Alexopoulos, et al., 1996 ). Selain itu penyebaran spora patogen Phytophthora infestans dipicu oleh keadaan lingkungan udara yang relatif lembab (di atas $80 \%$ seperti keadaan lingkungan di Wonosobo). Patogen tersebut juga dapat bertahan hidup di dalam umbi dan batang tanaman kentang sehingga infeksi pada umbi dapat terbawa sampai ke gudang penyimpanan (Adijaya, 2001). Gejala pada daun berupa hawar (blight) atau bercak berwarna abu-abu yang berukuran besar dengan bagian tengahnya agak gelap dan agak basah. Gejala serangan pada leher akar dan akar berupa busuk berwarna hitam. Serangan pada umbi berupa busuk basah umbi yang berwarna abu-abu atau hitam. Apabila umbi diinkubasikan dalam temperatur $15-20^{\circ} \mathrm{C}$, akan muncul konidia yang dibentuk dalam jumlah banyak, berupa tepung berwarna keabuan (Cholil, 1991).

Pengendalian penyakit busuk daun, busuk batang atau busuk umbi (late blight) oleh jamur patogen Phytophthora infestans, selama ini dilakukan dengan menyemprotkan fungisida sintetik Sandofan MZ 10/56 WP dengan konsentrasi yang dianjurkan, Benlate dengan konsentrasi yang dianjurkan dan Kocide 54. Kebiasaan para petani menyemprot pestisida secara serampangan menyebabkan timbulnya strain baru dari kapang-kapang patogen tersebut yang ditunjukkan adanya kekebalan kapang itu terhadap fungisida sintetis tertentu atau dosis efektif, fungisida sintetis dapat mencapai dua kali dosis anjuran. Untuk menghindari kondisi yang lebih parah, tindakan yang perlu dilakukan adalah mengganti fungisida yang biasa dipakai dengan fungisida yang berbeda bahan aktif dan cara kerjanya (mode of action). Pemakaian fungisida alternatif yang berisi kultur campuran kapang antagonis belum pernah dilakukan, oleh karena itu perlu dilakukan penelitian pendahuluan tentang efektivitas dan potensi kapang antagonis Pseudomonas fluorescense untuk mengendalikan kapang patogen Phytophthora infestans secara in vitro.

Pengendalian penyakit tanaman dengan fungisida dan bakterisida sintetis oleh para petani kentang selama ini tidak efektif, timbul banyak masalah yang merugikan bagi kehidupan manusia secara langsung atau tidak langsung diantaranya menimbulkan residu yang melekat pada hasil tanaman yang akan mengganggu kesehatan konsumen, pencemaran lingkungan serta membunuh organisme lainnya yang bukan sasaran. Penggunaan agen hayati berbahan baku biofungisida sehingga menjadi alternatif yang tepat untuk mengendalikan mikroba patogen penyebab penyakit pada tanaman budidaya. (Arwiyanto, 2003).

Agensia hayati meliputi organisme dan substansi yang dihasilkan yang dapat digunakan untuk mengendalikan organisme pengganggu yang merugikan (Anonim, 1996 dalam Marwoto, 2001). Salah satu jenis biopestisida adalah biofungisida berbahan aktif mikroorganisma sel jamur antagonis Trichoderma spp, yaitu fungisida penghambat pertumbuhan kapang patogen penyebab penyakit tanaman budidaya yang diharapkan efektif mengendalikan serangan kapang patogen Phytophthora infestans tanaman kentang serta aman bagi tanaman budidaya sebagai tanaman bukan sasaran.

Jamur antagonis Trichoderma spp dapat diisolasi dari tanah lokal, termasuk jamur selulolitik sejati karena mampu menghasilkan komponen selulase secara lengkap. Jamur tanah ini terdiri dari sembilan jenis yaitu $T$. piluliferum, $T$. polysporum, $T$. koningii, $T$. auroviride, $T$. amantum, T. harzianum, T. longibrachiatum, $T$. pseudokoningii, dan T. viride (Rifai, 1969 dalam Salma \& Gunarto, 1999). Jamur-jamur antagonis tanah isolat lokal seperti Trichoderma spp dilaporkan mempunyai aktivitas antagonisme yang 
kuat terhadap jamur patogen dengan mekanisme hiperparasitismenya dan antibiosisnya sehingga efektif menghambat pertumbuhan kapang patogen tanaman dengan mendegradasi dinding selnya. Dinding sel kapang patogen menjadi rusak kemudian mati melalui aktivitas enzim kitinasenya. Beberapa enzim kitinolitiknya hanya toksik pada kapang patogen penyebab penyakit tanaman budidaya tetapi tidak pada mikroorganisma lain dalam tanah dan tumbuhan inang (Kloepper et al., 1989).

Menurut Salma dan Gunarto (1999), Trichoderma spp mempunyai kemampuan menghasilkan enzim selulase sehingga dapat merusak dinding sel kapang patogen pada kelompok jamur famili Pythiaceae seperti Phytophthora infestans. Selain itu kapang tanah Trichoderma spp mempunyai kemampuan melakukan pelilitan dan penetrasi hifa patogen serta menghasilkan antibiotik yang bersifat toksin bagi patogen lawannya (Dennis \& Webster, 1971 dalam Salma dan Gunarto, 1999). Mekanisme antibiosis dilakukan dengan menghasilkan antibiotik yang bersifat toksin untuk membunuh $P$. infestans. Mekanisme antibiosis tergantung dari jenis dan sifat tanah sebagai substrat tumbuhnya. T. viride lebih suka pada kondisi tanah yang asam, apabila $T$. viride ini terdapat pada tanah yang asam kemungkinannya untuk memproduksi antibiotik lebih tinggi (Djafarudin, 2000).

T. viride umum digunakan untuk pengendalian patogen dalam bentuk tepung yang diaplikasikan dengan dosis $100 \mathrm{~kg} / \mathrm{ha}$ (Anonim, 2001). Keunggulannya yang lain adalah sebagai bioprotektan bagi tanaman muda HTI serta perkebunan. Beberapa keuntungan dari penggunaan biofungisida tersebut adalah mudah dimonitor dan berkembang biak, sehingga keberadaannya di lingkungan dapat bertahan lama serta aman bagi lingkungan, hewan dan manusia karena tidak menimbulkan residu kimia berbahaya yang persisten di dalam tanah atau terakumulasi di dalam makanan hasil budidaya pertanian (Yuliani, 2002).

Penelitian bertujuan untuk untuk mengetahui kemampuan jamur-jamur antagonis tanah isolat lokal dalam menghambat pertumbuhan kapang patogen Phytophthora infestans secara in vitro. Selain itu, penelitian dilanjutkan dengan uji antagonisme antara jamur patogen dan jamur antagonis isolat lokal yang telah ditemukan. Penelitian tentang efektifitas pengaruh inokulasi jamur antagonis isolat lokal tsb terhadap pencegahan thd infeksi oleh kapang patogen Phytophthora infestans pada tanaman kentang yang ditanam di rumah kaca juga penting dilakukan. Diversifikasi bahan aktif biofungisida perlu dilakukan, mengingat Indonesia sebagai negara tropis mempunyai potensi menghasilkan jenis agen hayati yang tinggi keanekaragamannya.

Biofungisida yang berisi mikroorganisma jamur antagonis isolat lokal sebagai bahan aktif utamanya, secara ekonomi penggunaannya lebih murah dan efektif dibandingkan dengan fungisida kimiawi, karena sekali diintroduksikan ke dalam tanah atau medium pembawa yang tepat akan dapat bertahan dalam periode yang cukup lama. Selain itu aplikasinyapun dapat dilakukan seperti aplikasi pada fungisida kimiawi. (Yuliani 2002).

\section{BAHAN DAN METODE}

Penelitian in vivo dilakukan di rumah kaca Laboratorium Pengamatan Hama dan Penyakit Kedu, Temanggung dan penelitian in vitro dilakukan di Laboratorium Mikrobiologi Jurusan Biologi FMIPA Universitas Diponegoro.

\section{Isolasi dan identifikasi jamur-jamur antagonis tanah lokal}

Isolat jamur-jamur antagonis isolat lokal diisolasi dari tanah tempat tanaman kentang tumbuh baik yang teridentifikasi sakit ataupun yang tidak oleh patogen Phytophthora infestans. Isolasi dilakukan pada lahan pertanaman kentang yang sakit dan yang tidak terinfeksi Phytophthora infestans. Isolasi dilakukan dengan cara isolasi langsung (direct plating), yaitu : tanah lokal diambil dan diletakkan pada cawan petri yang berisi medium TEA steril yang telah ditambahkan chloramfenikol 50 ppm, kemudian diinkubasi pada suhu ruang selama 3 hari. Koloni jamur yang menunjukkan morfologi koloni yang berbeda kemudian masing-masing dipisahkan ke dalam medium PDA kemudian diidentifikasi menurut buku Barnett dan Hunter, 1972. 
2.Isolasi dan identifikasi jamur Phytophthora infestans.

Isolat Phytophthora infestans diisolasi dari daun kentang yang positif terinfeksi Phytophthora infestans. Isolasi dilakukan dengan cara isolasi langsung (direct plating), yaitu : daun kentang diambil dan diletakkan pada cawan petri yang berisi TEA steril yang telah ditambahkan chloramfenikol 50 ppm, kemudian diinkubasi pada suhu ruang selama 3 hari. Koloni kapang yang menunjukkan ciri-ciri Phytophthora infestans dipindahkan dalam medium PDA lainnya dalam cawan petri secara aseptik dan diinkubasi pada suhu ruang selama 3 hari. Identifikasi menurut Barnett dan Hunter, (1972) untuk memperoleh isolat murni Phytophthora infestans.

3. Uji Antagonisme jamur antagonis isolat lokal terhadap kapang patogen Phytophthora infestans secara In vitro

Isolat Phytophthora infestans dibiakkan pada media PDA (Potao Dekstrose Agar) di dalam cawan petri dan diinkubasi selama 5 x 24 jam pada suhu $30^{\circ} \mathrm{C}$, kemudian dibuat cetakan potongan miselium berbentuk bulat dengan diameter $0,5 \mathrm{~cm}$. Satu potongan miselium ini kemudian diletakkan berdampingan dengan cetakan miselium koloni jamur antagonis isolat lokal (dual plating). Sebagai kontrol, kapang patogen Phytophthora infestans ditumbuhkan pada medium PDA yang tidak diinokulasikan terlebih dahulu dengan biakan sel jamur antagonis isolate lokal.

\section{HASIL DAN PEMBAHASAN}

\section{Isolasi patogen penyebab busuk daun dan umbi tanaman kentang}

Kapang patogen Phytophthora infestans berhasil diisolasi dari beberapa lembar daun kentang yang telah positif terinfeksi kapang patogen tersebut yang diambil dari lokasi perkebunan (pembibitan) kentang di Kledung, Kedu Temanggung Jawa Tengah (Gambar 1 dan 2 ). Metode isolasi menggunakan metode isolasi secara langsung (direct method). Beberepa kapang antagonis (3 buah) juga telah berhasil diisolasi dan positif menghambat pertumbuhan kapang patogen Phytophthora infestans. Penghambatan yang kuat terjadi pada pertumbuhan koloni jamur Trichoderma $s p$ yang ditumbuhkan pada koloni kapang patogen Phytophthora infestans (Gambar 2).

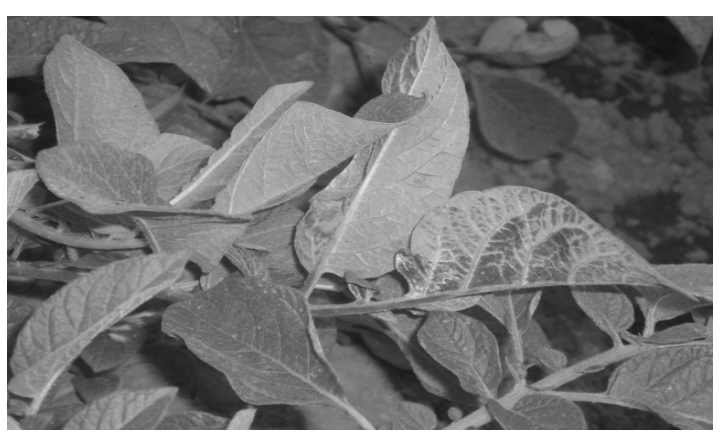

Gambar 1: Busuk daun (late blight) pada daun tanaman kentang oleh Kapang patogen Phytophthora infestans

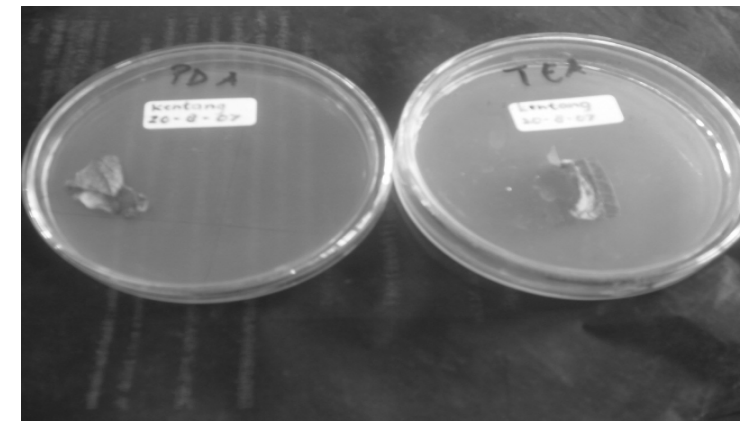

Gambar 2: Isolasi langsung daun tanaman kentang yang terinfeksi kapang patogen Phytophthora infestans pada medium PDA dan TEA

Koloni kapang patogen Phytophthora infestans pada medium PDA berwarna putih dengan tekstur permuakaan berwarna wolly. Sporangia berbentuk pyriform mempunyai papila berwarna hialin serta permukaannya halus. Sporangiofor bercabang-cabang simpodial, berwarna hialin (Gambar 3). 



Gambar 3: Koloni dan gambar mikroskopi kapang patogen Phytophthora infestans pada medium PDA

\section{Isolasi kapang -kapang tanah isolat lokal pada pertanaman kentang}

Dari hasil isolasi jamur tanah pada medium PDA diperoleh 3 isolat kapang antagonis, baik yang diisolasi dari pertanaman kentang yang sakit atau yang tidak. Pemilihan isolat didasarkan pada perbedaan morfologi koloni (warna dan bentuk koloni) isolat jamur pada kedua medium tersebut untuk tiap-tiap sampel tanah. Dengan demikian tidak menutupi kemungkinan terdapat isolat-isolat jamur yang sama yang berasal dari beberapa sampel tanah tersebut (Gambar 4).


Gambar 4: Koloni-koloni kapang antagonis yang dapat diisolasi dari tanah pertanaman kentang pada medium PDA.

\section{Uji antagonisme secara in vitro}

Dari 7 isolat jamur yang diperoleh pada medium PDA, 3 isolat di antaranya

bersifat antagonis terhadap kapang patogen Phytophthora infestans dan berdasarkan pada persamaan sifat morfologi koloninya (warna dan bentuk koloni), maka dari 7 isolat jamur ini dapat dikelompokkan menjadi 3 isolat jamur antagonis yang sama.

Pengamatan secara mikroskopis menunjukkan bahwa dari 1 kelompok jamur antagonis ini kelompok 1 merupakan kelompok/ marga Trichoderma spp. yang dicirikan dengan adanya banyak percabangan konidiofor dan konidium terbentuk secara bergerombol pada permukaan sel konidiofornya (Gambar 5). Mekanisme penghambatan yang terjadi pada uji antagonisme ini adalah hiperparasit yang dapat diamati dengan pertumbuhan miselium Trichoderma spp. yang menutupi seluruh permukaan medium termasuk koloni Phytophthora infestans. Pada hari keenam uji penghambatan jamur Trichoderma $s p$ terhadap pertumbuhan kapang patogen Phytophthora infestans secara in vitro mengalami penghambatan yang paling kuat yang ditandai dengan penutupan koloni kapang Trichoderma $s p$ pada hari keenam umur pertumbuhan Phytophthora infestans (Gambar 6).
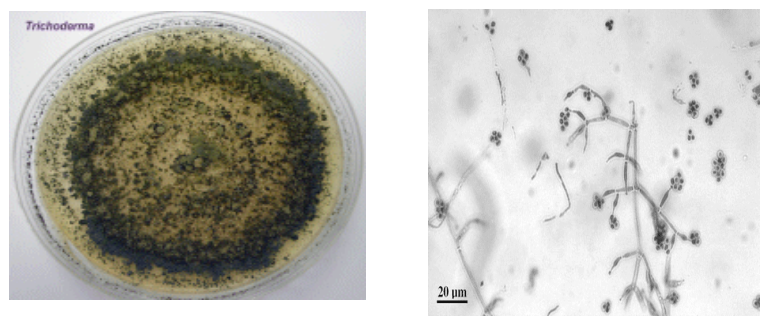

Gambar 5: Koloni dan mikroskopi kapang antagonis isolat lokal Trichoderma $s p$ pada medium PDA

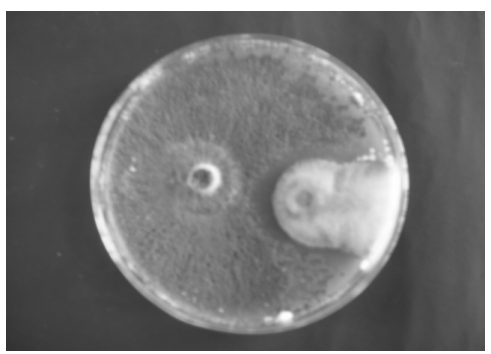

Gambar 6: Penutupan koloni kapang patogen Phytophthora infestans oleh kapang antagonis Trichoderma sp. Pada hari keenam uji antagonisme

Pada isolasi jamur tanah dengan medium PDA ini selain marga Trichoderma spp., juga didapatkan 2 kelompok jamur antagonis yang lain yang berbeda sifat morfologi koloninya. (Tabel 1). Isolat jamur antagonis kelompok 2 merupakan marga Aspergillus. Hal ini dapat dilihat dari morfologi jamur yang khas yaitu adanya vesikel yang berbentuk bulat hingga lonjong, fialid yang 
terbentuk di seluruh permukaan vesikel dan konidium yang terbentuk secara berantai pada fialid. Koloni pada medium PDA berwarna hitam yang permukaannya kasar (Gambar 7).


Gambar 7: Koloni dan mikroskopi kapang antagonis isolat lokal Aspergillus sp pada medium PDA

Adapun kelompok 3 masih merupakan kelompok jamur yang belum teridentifikasi dengan ciri morfologi yang sama dengan gambar 9. Pada pengamatan secara mikroskopis pada jamur yang belum bisa teridentifikasi hanya dijumpai adanya hifa yang bersekat dan tidak ditemukan adanya konidium atau organ-organ lain yang yang merupakan ciri khas dari jamur.



Gambar 8: Uji antagonisme koloni kapang patogen Phytophthora infestans oleh kapang antagonis Aspergillus sp. Pada hari keenam pada medium PDA

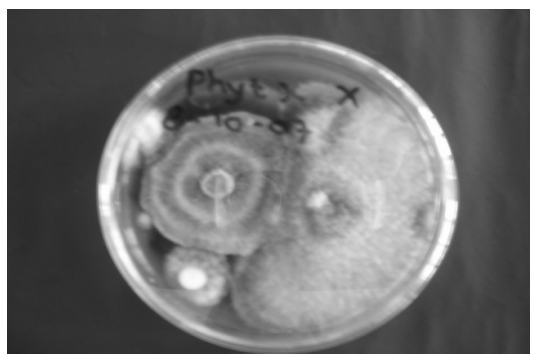

Gambar 9: Uji antagonisme koloni kapang patogen Phytophthora infestans oleh kapang antagonis yang belum diketahui jenisnya.
Mekanisme penghambatan yang terjadi kelompok jamur 2 dan 3 (Aspergillus dan jamur yang belum bisa diidentifikasi) pada uji antagonisme ini adalah antibiosis. Hal ini dapat diketahui dengan terbentuknya zone penghambatan di sekitar koloni jamur antagonis (Gambar 8). Zona penghambatan ini hanya bersifat sementara karena jika waktu inkubasi diperpanjang maka koloni Phytophthora infestans mampu tumbuh terus melewati zona penghambatan tersebut. Sedangkan pada kelompok 1 (Trichoderma sp), mekanisme penghambatannya diduga adalah hiperparasit dimana koloni jamur antagonis tumbuh menutupi seluruh permukaan medium termasuk koloni Phytophthora infestans. Gambar uji antagonisme tersebut dapat dilihat pada Gambar 1.

\section{KESIMPULAN}

Kapang antagonis isolat lokal Trichoderma lignorum dapat menghambat pertumbuhan kapang patogen Phytophthora infestans secara in vitro.

\section{DAFTAR PUSTAKA}

Adijaya S. Dian. 2001. Kentang Tak Harus Kulit Kering. Trubus . 376: 50.

Alexopolous C.J., Mims, C.W., Blackwell M. 1996. Introductory Mycology. John Wiley \& Sons, Inc. Canada America.

Anonimous.2002. Pedoman Penerapan Agen Hayati Dalam Pengendalian OPT Tanaman Sayuran. Direktorat Jenderal Bina Produksi Hortikultura Direktoratv Perlindungan Hortikultura. Jakarta. 49hal.

Bertha Hapsari, 2003. Stop Fusarium dengan Trichoderma. Trubus 404- XXX. Hal. 42-43).

Cholil, A dan Latief Abadi. 1991. Penyakitpenyakit penting tanaman pangan. Pendidikan Program Diploma Satu Pengendalian Hama Terpadu. Fakultas Pertanian Universitas Brawijaya Malang.

Cook, R. J. \& K.F. Baker. 1983. The Nature and Practice of Biological Control of Plant Pathogens. APS Press, Am. Phyt. Soc., Minnesota. 539 p.

De La Cruz, J., J.A. Pintor-Toro, T. Benitez \& A. Liobell. 1995. Purification and Characterization o fan Endo- -1,6- 
Glucanase from Trichoderma harzianum that is related to its Mycoparasitism. $J$. Bacteriol. 177: 1864- 1871.

Domsch, K. H., W, Gams, \& T. Anderson. 1980. Compendium of Soil Fungi. Academic Press. London.

Djafarudin. 2000. Dasar-dasar Pengendalian Penyakit Tanaman. Bumi Aksara. Jakarta.

Harman, G.E., C.K. Hayes, M. Lorito, R.M Broadway, A. Di Pietro, C. Peterbauer \& Tronsmo. 1993. Chitinolytic Enzymes of Trichoderma harzianum: Purification of Chitobiosidase and Endochitinase. Phytopathology 83: 313-318.

Hartree, E.F. 1972. Determination of Protein: A Modification of the Lowry Method that Gives a Linier Photometric Response. Anal. Biochem. 48: 422- 427.

Lorito, M. 1998. Chitinolitic Enzymes and Their Genes, p. 73-99. In Harman, G.E., and C.P. Kubicek. Trichoderma and Gliocladium Vol. 2. Enzymes, Biological Control and Commercial Application. Taylor and Francis, London.

Katayama, Katsumi, dan Teramoto, Takeshi. 1997. Seed Potato Production and Control of Insect Pest and Diseases in Indonesia, dalam
Agrochemicals Japan Journal. Japan-Plant Protection.

Panda, F.T. 1999. Regulation and cloning of microbial chitinase genes. Appl.Microbiol. Biotechnol. 51: 141-151.

Rukmana, Rachmad. 1997. Kentang: Budidaya dan Pasca Panen. Yogyakarta: Kanisius.

Tokuyasu, K., M.O. Kameyama and K. Hiyasi. 1996. Purification and characterization of extracelular chitin deacetylase from Collletotrichum lindemuthianum. Biosci. Biotech. Biochem. 60: 1598-1603.

Ueda, M., M. Shiro, T. Kawaguchi and M. Aray. 1996. Expression of chitinase III gen of Aeromonas 10S-24 in E. coly. Biosci. Biotech. Biochem. 60: 1195-1197.

Vessey, J.C. \& G.F. Pegg. 1973. Autolysis and Chitinase Production in Cultures of Verticillium alboatrum. Trans. Br. Mycol. Soc. 60: 133-143.

Wibowo, Arif dan Suryanti. 2003. Isolasi dan Identifikasi Jamur-jamur Antagonis terhadap Patogen Penyebab Penyakit Busuk Akar dan Pangkal Batang

Pepaya. Jurnal Fitopatologi Indonesia (Vol 7) No. 2: 38-44 pp. 